\title{
The Trust in Online Shopping during COVID-19: Case Study from Kosovo
}

\author{
Abetare Prebreza, Blerona Shala \\ Faculty of Economics, University of Prishtina "Hasan Prishtina", Prishtina, Kosovo \\ Email: abetare.prebreza@gmail.com
}

How to cite this paper: Prebreza, A. and Shala, B. (2021) The Trust in Online Shopping during COVID-19: Case Study from Kosovo. Open Access Library Journal, 8: e7288

https://doi.org/10.4236/oalib.1107288

Received: March 7, 2021

Accepted: April 27, 2021

Published: April 30, 2021

Copyright $\odot 2021$ by author(s) and Open Access Library Inc.

This work is licensed under the Creative Commons Attribution International License (CC BY 4.0).

http://creativecommons.org/licenses/by/4.0/ (c) (i) Open Access

\begin{abstract}
Consumer trust with online shopping is directly dependent on a few factors. There is a constant dilemma in the market related to the question which online shopping determinants affect the customer trust. Online purchasing is becoming increasingly common as a purchasing mode. This paper deals with the analysis of customer satisfaction, with the aim of utilizing the empirical research on the Kosovo market in COVID-19 period in order to determine the connection between customer trust and certain determinants of online shopping. The paper was conducted using the questionnaire instrument and there are two hundred and fifty (250) respondents from Kosovo. Moreover, in the paper three (3) hypothesis are presented the results that come out of it are very interesting. For hypothesis testing and recommendation was used Correlation Analysis.
\end{abstract}

\section{Subject Areas \\ Consumer Behavior}

\section{Keywords}

COVID-19, Online Shopping, Customer Trust, Kosovo

\section{Introduction}

The Internet shopping as one of the types of electronic shopping has proliferated rapidly since the middle of 1990s where Web technologies have played a major role in this decade (Trong, Vu Khanh, \& Gim, 2014) [1]. The internet has become an essential for us and is the most important way to communicate and to connect with others. We can gather any information's we need from the internet as well as we doing the online shopping, online banking, online marketing, online affiliations, online socialize, online tutorials, online course, online advertis- 
ing and others. Online shopping is a form of e-shopping which permits consumers to directly purchase goods or services from a seller by using the Internet (Singh \& Sailo, 2013) [2]. It has propelled in no small extent of changes in the attitude and behavior of people all over the world. Internet shopping has been widely accepted as a way of purchasing products and services it has become a more popular means in the Internet world (Bourlakis, Papagiannidis, \& Fox, 2008) [3]. Shopping online has emerged as one of the most popular Internet applications. Online shopping has been shown to provide more satisfaction to modern consumers seeking convenience and speed. So, online shopping has become very important in the 21 st century as most of the people are loaded with hectic schedule and online shopping is considered as the easiest and most convenient mode for shopping. The internet is offering businesses innovative methods to manage information and better serve their customers (Aref \& Okasha, 2019) [4]. Online shopping is the best way to purchase goods and services.

The global crisis of COVID-19 pandemic has started to ravage the world economy and healthcare, igniting much fear, panic, and uncertainty among billions of people. As lockdowns being implemented in many places, panic buying has emerged as a reliable feature of the Coronavirus outbreak. In this time, the internet has played a significant role in our daily life in that people can talk through the internet to one who is actually on the other side of the Earth, can send e-mail around the clock, can search information, can play game with others, and even can buy things online (Katawetawaraks \& Wang, 2011) [5].

\section{Overview of Literature Review}

Online shopping is the easy solution for busy life in today's world especially during the COVID-19. Also, it is important to know about the convenience in online shopping. The author (Ahmad, 2002) [6] studied about the convenience in online shopping. Online shopping indicates electronic shopping to buy products or services directly from the seller through the Internet. Now people have multiple options to choose their products and services while they are shopping through an online platform (Rahman, Islam, Esha, Sultana, \& Chakravorty, 2018) [7]. Electronic shopping has become a large and important segment in the new digital economy over the last 10 years (Hostler, Yoon, \& Guimaraes, 2012) [8]. The vast increase in e-shopping, together with the development of information technology, has had a profound impact on the world economy. E-shopping enables regional traders to be less local and more global and also reduces trade barriers (Sung, 2006) [9]. The Internet has become one of the most popular shopping channels and has changed customers' shopping habits, largely through rapid technological development. Online shopping is considered as the most convenient and easiest mode of shopping. The authors (Berry, Seiders, \& Grewal, 2002) [10] defined online shopping as "a reduction of the opportunity costs of effort and time involved in shopping activities".

So, online shopping indicates electronic shopping to buy products or services directly from the seller through the Internet. The literature shows that behavior 
of the online consumers is affected by different factors such as: convenience, pricing and quality, website design, saving time, security and socialization, which will be shown in the text below.

\subsection{Convenience}

Internet buying is one of the widely and commonly used mediums for convenient shopping Webster's Dictionary defines convenience as "anything that adds to one's comfort or saves work; useful, handy or helpful device, article, service, etc". In the marketing literature, the concept of convenience was introduced by (Copeland, 1923) [11], who referred to convenience goods as those that the consumer purchases frequently and immediately at easily accessible stores. The author (Copeland, 1923) [11] and other researchers (Bucklin, 1965) [12] have used the convenience construct within the domain of the "convenience" classification of products, which relates to low risk or low involvement in purchasing (Brown, 1989) [13]. Online marketers need to ensure online shopping process easy and simple (Hamza \& Saidalavi, 2014) [14]. Much of the literature on consumer convenience in a traditional retailing environment has revealed two factors of primary importance in delivering convenient service to customers: time-saving and effort minimization efforts (Etgar, 1978; Kotler and Zaltman, 1971; Seiders et al., 2000, 2005, 2007; Yale and Venkatesh, 1986). Berry et al. (2002) [10] and Seiders et al. (2007) have extensively reviewed the literature on consumer convenience in a service economy and define "service convenience" as consumers' time and effort perceptions related to buying or using a service. In online shopping, confidence is one of the most critical issues affecting the success or the failure of Internet retailers (Prasad \& Aryasri, 2009) [15].

Prior literature on online service quality has identified several service convenience features unique to virtual shopping indicating some of the ingredients constituting online service quality, such as ease of use, interactivities, information search, the depth and richness of information, and security (Parasuraman, Zeithaml, \& Berry, 1985) [16].

\subsection{Pricing}

Professional literature describes pricing as an important factor in customer satisfaction, due to the fact that consumers always direct their attention to pricing when assessing the product and service value (Joseph Cronin, Brady, \& Hult, 2000) [17] from the consumer's perspective, price is what is given up or scarified to obtain a product (Zeithaml V., 1988) [18]. A number of studies have determined that the pricing is significantly related to customer satisfaction (Jiang \& Rosenbloom, 2005) [19]. Pricing directly affects the perception on the transaction's delivered value and usability, and, consequently, customer satisfaction (Kim, Xu, \& Gupta, 2012) [20]. Negative perception on pricing makes customers feel dissatisfied and disloyal (Mittal, 1989) [21]. According to (Keaveney, 1995) [22], more than half e-customers who changed the retailer have done it due to pricing. Pricing has a special influence onto the satisfaction of the experienced 
online customers (Jiradilok, Malisuwan, Madan, \& Sivarak, 2014) [23]. When the customer is certain about the transaction, their demand for financial benefit increases. Competitive pricing should be placed to attract online shoppers to the website for encouraging them to purchase. Customers always search for competitive prices and compare with other online retailers before purchase (Hamza \& Saidalavi, 2014) [14]. Many customers expect online stores to offer their products and services at the lower price in comparison to traditional stores. Discounts while purchasing influence consumers to believe in prices, and ultimately they affect their satisfaction (Biswas \& Blair, 1991) [24]. While shopping online, customers cannot see or test the product; hence, they are not certain that the delivered product is identical to the one on the website. Consequently, price perception has a more significant role (Liu \& Arnett, 2000) [25]. As online stores offer consumers a range of products and services, consumers can compare product prices from different websites and find the products at lower prices than the prices in the stores (Lim \& Dubinsky, 2004) [26] some websites. Such approach turns online shopping into a game, transforming it into fun and entertainment (Prasad \& Aryasri, 2009) [15]. Ultimately, pricing can be the reason for renouncing the product or service or making a sacrifice in order to have the product or service (Zeithaml V., 1988) [18].

\subsection{Quality}

The quality of products and services in online shopping has a positive impact on customer satisfaction (Lin, $\mathrm{Wu}, \&$ Chang, 2011) [27]. The perceived product quality is defined as the consumer's judgment about a product's overall excellence or superiority (Chen \& Dubinsky, 2003) [28]. Author (Keeney, 1999) [29] indicated that minimizing the product cost and maximizing the product quality are to be regarded as major factors in the success of e-shopping. Authors (Mentzer \& Williams, 2008) [30] pointed out that the perceived product performance is the most powerful determinant related to satisfaction. Conversely, a number of studies dealing with online shopping argue that the service quality has a positive influence on customer satisfaction (Kim \& Stoel, 2004) [31]. Quality is an intrinsic property of a product. Product quality is the expected standard of product or service excellence (Parasuraman, Zeithaml, \& Berry, 1985) [16]. The quality of service determines whether the customers will develop strong and loyal relationships with online retailers. Regarding authors (Guo, Choon Ling, \& Liu , Evaluating Factors Influencing Consumer Satisfaction towards Online Shopping in China, 2012) [32], the quality of service is interpreted as the degree of help by online retailers in providing an efficient and effective purchase, shipping and delivery of products and services. By providing and sending information either via formal or informal platforms, online vendors increase the expectations of their customers and add value to their services (Christodoulides \& Michaelidou, 2010) [33]. Hence, it is very important to manage the quality in business to ensure the best service quality for consumers. Service quality is the ability implying firstly to anticipate, and secondly to meet the requirements by 
consumers. This is the reason why providing the service quality has an important role in increasing the customer satisfaction. Better website quality significantly influences the consumer's decision to shop online.

\subsection{Website Design}

Customers can be influenced by the image of the web site when they decide what website or buyer they should buy from (Lim \& Dubinsky, Consumers' perceptions of e-shopping characteristics: An expectancy-value approach, 2004) [26]. Not only should companies create their secured website, but also should create it to be more attractive and more useful. Online stores can change a shopper into a buyer if the stores provide variety and useful information of product, good customer service, and easy-to-access website (Laudon \& Traver, 2009) [34]. Their websites should have enough information but should not be too overwhelming. Putting unstructured or useless information in the website can reduce internet usefulness and ease of use (Bigné-Alcañiz, Ruiz-Mafé, Aldás-Manzano, \& Sanz-Blas, 2008) [35]. Also, companies and sellers should double-check any single words in their website to reduce mistakes and customers' misunderstanding. Information quality and visual design is important effect on repurchasing (Koo, Kim, \& Lee, 2008) [36]. The willingness to purchase online will be low if the online store lacks of ease in searching and comparing shopping, and product updates. Online store should make their website to be easy for consumers to search product and service. Making web designs and portals novel and sophisticated and web atmospherics friendly is a key to attract visitors. Moreover, if online stores want to convert visitor into buyer, they should improve their website by offering customer a comfortable, logical, interesting and hassle-free process and easy language by creating fast website with functional design as smooth as possible (Broekhuizen \& Huizingh, 2009) [37]. Online payment process is another issue that should be taken care of because it affects the willingness to pay ( $\mathrm{Lu}$ Wang, Zhang, Ye, \& Nguyen, 2005) [38]. Online stores should make their payment process to be as easy and secure as possible. To sum, if online stores want to increase the customer, they should take care of their website design to be more user-friendly (Bigné-Alcañiz, Ruiz-Mafé, Aldás-Manzano, \& Sanz-Blas, 2008) [35].

\subsection{Saving Time}

Saving time is one of the most influential factors in online shopping. Time is the main resource that consumers spend when they purchase online or in traditional stores (Bhatnagar, Sanjog, \& Raghav, 2000) [39]. Browsing the online catalog during online shopping saves time and reduces stress compared to traditional shopping. According to (Rohm \& Swaminathan, 2004) [40], one of the possible explanations why buying online saves time is eliminating the travel required to go to the store. On the other hand, according to (Corbett, 2001) [41], time saving does not present a motivation factor for consumers to buy online, since it 
takes some time for the delivery of goods. In (Morganosky \& Cude, 2000) [42], a factor in time saving was designated as the primary one among those consumers who already experienced e-shopping. In addition, there is a difference between online consumers and offline consumers. Online consumers are concerned with purchase benefits, time saving and choice, while offline consumers are anxious about security, privacy, and delivery on time (Goldsmith \& Bridges, 2000) [43]. According to customer perception, the advantage of online shopping is related to purchase simplicity and the reduction of time spent on shopping (Kim \& Lim, 2001) [44]. One of the most significant problems people generally deal with concerns the perceived time pressures. According to some authors, time pressures present the degree one realizes there is no time left in relation to daily obligations and chores. Since online shopping can be completed anywhere and anytime, this greatly simplifies the lives of its users; by purchasing online, consumers avoid traffic jams, they do not have to search a parking lot, and they do not have to queue nor be a part of the crowd in the store (Childers, Carr, Peck, \& Carson, 2001) [45].

\subsection{Security}

Security is one of the most important online shopping specificities (Pilík \& Juřičková, 2016) [46]. Security is defined as the ability of the website to protect consumers' personal data from any unauthorized disclosure of information during electronic transactions (Guo, Choon Ling, \& Liu, Evaluating Factors Influencing Consumer Satisfaction towards Online Shopping in China, 2012) [32]. Security is considered to be an important factor perceived seriously by online purchase consumers (Eid, 2011) [47]. Since online shopping usually implies payment by debit or credit card, consumers sometimes direct their attention towards the information about the retailer as a means of protection (Lim \& Dubinsky, 2004) [26]. The willingness of consumers to visit online stores and purchase there is directly related to the consumers' confidence in providing personal information and credit card payments (Lee \& Jin, 2019) [48]. Consumers tend to buy a product from a vendor whom they trust or a brand product they are familiar with (Chen \& He, 2010) [49]. Security tends to be a great problem preventing consumers from purchasing online, as consumers are concerned that they will be deceived by vendors who will misuse their personal information, especially their credit card data (Comegys, Hannula, \& Väisänen, 2009) [50].

\subsection{Socialization}

While some customers likely to be free from salesperson pressure, many online shopping would feel difficult to make a choice and thus get frustrated if there is no experienced salesperson's professional assistance (Prasad \& Aryasri, 2009) [15]. Moreover, some customers are highly socially connected and rely on other peoples' opinions when making purchase decision tend. There are also consumers who sometimes shop at traditional store because they want to fulfill their en- 
tertainment and social needs which are limited by online stores (Prasad \& Aryasri, 2009) [15]. Dissatisfaction with online shopping: customers' past online shopping experience often affect their future purchase decision. In online shopping, for example, they may get unwanted product or low quality products, product does match what is described or expected (Comegys, Hannula, \& Väisänen, 2009) [50]. The product may be fragile, wrong, or not working. Some online sellers may not agree to refund those products even though it is not what the customer wanted. Delivery is another thing that affects online purchasing decision. Slow or late shipping, for instance, makes customer walk away from online shopping (Comegys, Hannula, \& Väisänen, 2009) [50]

\section{Methodology}

\subsection{Population and Sample}

The population of this research consists of all buyers who have used online shopping during the first three months of the appearance of the COVID-19 virus in our country. The reason for selecting this research is that no one was initiated at the time of compiling the questionnaire. The selection of the sample in this research is of the random type (convenience sample), which is not based on a certain probability of selection but on the ease of contact with persons or entities that belong to a certain interest group for research. Consequently, the sample selected for this research consists of two hundred and fifty (250) respondents of all age groups, and with an acceptable spread across all settlements of the Republic of Kosovo which is a very representative number for the population. Given that if the sample covers $2 \%$ of the population, many researchers consider it a useful sample, the same can be determined in the case of this sample, as it covers $1.25 \%$ of the population. The divergences of the respondents of this research in terms of age, gender, place of residence and education help to conduct a more detailed analysis, more likely to notice possible changes, but also with greater opportunities to understand in more detail the problem of this issue in our country.

\subsection{Instrument and Procedure}

The research instrument of this study is the questionnaire as an easier tool to access with the respondents. Thus, before starting the field survey, we conducted a pilot survey at to a small group of people, and after consulting with field experts, we implemented the necessary improvements. A considerable number of questionnaires were consulted which were accurate. This research, as a necessity to extract the necessary information, contains a total of fifty-two questions (52) questions, which are mainly closed-ended questions with alternatives as well as questions requiring the evaluation of statements by the Likert scale (1 to 5). The collection of all data was carried out during the months of June to August this year. The survey of respondents was conducted electronically through social networks and e-mail as the easiest forms to reach answers. The questionnaire 
was welcomed by the respondents as it has been a novelty for this time period and the comments received have been quite encouraging.

\subsection{Participants}

Participants in this research are a total of two hundred and fifty two (252) respondents from all over the Republic of Kosovo. In Table 1 below are shown the demographic characteristics of participants:

Table 1. Demographic characteristics of participant.

\begin{tabular}{|c|c|}
\hline \multicolumn{2}{|c|}{ Demographic characteristics of participant } \\
\hline Sex & \\
\hline Female & $72.2 \%$ \\
\hline Male & $27.8 \%$ \\
\hline \multicolumn{2}{|l|}{ Age groups (years) } \\
\hline $18-25$ & $23.8 \%$ \\
\hline $26-35$ & $47.6 \%$ \\
\hline $36-45$ & $19.8 \%$ \\
\hline $46-55$ & $7.1 \%$ \\
\hline $56-65$ & $1.2 \%$ \\
\hline 65 and over & $0.4 \%$ \\
\hline \multicolumn{2}{|l|}{ Educational level } \\
\hline Primary & $0.8 \%$ \\
\hline Secondary & $9.5 \%$ \\
\hline Bachelor & $33.3 \%$ \\
\hline Master & $46.8 \%$ \\
\hline Doctoral & $0.8 \%$ \\
\hline \multicolumn{2}{|l|}{ Employment } \\
\hline Public Sector & $38.5 \%$ \\
\hline Private Sector & $36.5 \%$ \\
\hline NGOs & $8.3 \%$ \\
\hline Self-employed & $4.4 \%$ \\
\hline Unemployed & $12.3 \%$ \\
\hline \multicolumn{2}{|c|}{ Net individual monthly income (in euros) } \\
\hline Under 250 & $14.3 \%$ \\
\hline From 251 to 500 & $44.4 \%$ \\
\hline From 501 to 750 & $22.6 \%$ \\
\hline From 751 up to 1000 & $9.5 \%$ \\
\hline Over 1000 & $9.1 \%$ \\
\hline \multicolumn{2}{|l|}{ Marital status } \\
\hline Single & $49.2 \%$ \\
\hline \multicolumn{2}{|l|}{ Cohabiting with } \\
\hline their partner & $5.6 \%$ \\
\hline Married & $41.7 \%$ \\
\hline Divorced & $3.6 \%$ \\
\hline \multicolumn{2}{|l|}{ Region (where lives) } \\
\hline Prishtina & $73.4 \%$ \\
\hline Mitrovica & $6.3 \%$ \\
\hline Peja & $7.5 \%$ \\
\hline Gjakova & $5.2 \%$ \\
\hline Prizren & $2.8 \%$ \\
\hline Gjilan & $4.8 \%$ \\
\hline
\end{tabular}




\section{Results}

Hypothesis testing is the process of drawing conclusions about data by applying statistical tests to a sample. Regression analysis is used to estimate the relationship between dependent and independent variables. Rather, this analysis helps us understand the impact that independent variables have on the dependent variable. This analysis is one of the most widely used techniques in social science research.

To reach a conclusion, an assumption must be made to test the hypothesis. Hypothesis zero $\mathrm{H} 0$ begins with the assumption that hypothesis zero is true and indicates a statement or assumption and must be accepted as correct if there is no evidence against it. Alternative Hypothesis $\mathrm{H} 1$ is the opposite of the null hypothesis when the assertion or assumption that the null hypothesis is not accepted as correct and accepted after the null hypothesis is rejected.

\subsection{Research Questions}

Below are the initiating questions where this paper is concentrated. The research questions are as follows:

1) Is there a significant correlation between the design of a webpage and the convenience of services/products offered during COVID-19?

2) Is there a significant correlation between price-quality and time saving while using services/products offered online during COVID-19?

3) Is there a significant correlation in socialism during the online shopping with family and friends and the online shopping behavior during COVID-19?

\subsection{Testing the First Hypothesis}

H1o: There is a significant positive correlation between the Design of webpage of finding Services/Products and Convenience of Services/products offered with a great variety during COVID-19.

H1a: There is no significant correlation between the Design of webpage of finding Services/Products and Convenience of Services/products offered with a great variety during COVID- 19 .

The results from the correlation analysis test show that there is a strong positive correlation between the tested variables, which are statistically expressed with a correlation level of $\mathrm{r}=0.329$ and a significance level of Sig $=0<0.05$ (Table 2). The analysis shows that with the increase of the variable $X$ the variable $\mathrm{Y}$ decreases, which means that the more people perceive the design of the webpage as suitable, the more they would find it convenient to use services and find products online. They will be willing to use it now or in the future. Consequently, this makes us accept the null hypothesis. These results show a great similarity with the previous findings of different researchers on the relationship between these two variables.

\subsection{Testing the Second Hypothesis}

H2o: There is a significant positive correlation between Price and quality of 
services/products during COVID-19 and Time saving while using services/products offered online.

H2a: There is no significant correlation between Price and quality of services/products during COVID-19 and Time saving while using services/products offered online.

The results from the correlation analysis test show that there is a strong positive correlation between the tested variables, which are statistically expressed with a correlation level of $\mathrm{r}=0.349$ and a significance level of Sig $=0<0.05$ (Table 3). The analysis shows that with the increase of the variable $\mathrm{X}$ the variable $\mathrm{Y}$ decreases, which means that the more people find the time using services/products offered online especially during COVID-19, the more they would check on the price ranges and quality offerings since the time is right due to the circumstances. Consequently, this makes us accept the null hypothesis. These results show a great similarity with the previous findings of different researchers on the relationship between these two variables.

Table 2. Testing the first hypothesis.

\begin{tabular}{|c|c|c|c|}
\hline \multicolumn{4}{|c|}{ Correlations } \\
\hline & & $\begin{array}{c}\text { The Design of webpage } \\
\text { of finding } \\
\text { Services/Products }\end{array}$ & $\begin{array}{l}\text { Convenience of } \\
\text { Services/products offered } \\
\text { with a great variety }\end{array}$ \\
\hline The Design of webpage & Pearson Correlation & 1 & $0.329^{* *}$ \\
\hline $\begin{array}{c}\text { of finding } \\
\text { Services/Products }\end{array}$ & Sig. (2-tailed) & & 0.000 \\
\hline during COVID-19 & $\mathrm{N}$ & 250 & 250 \\
\hline Convenience of & Pearson Correlation & $0.329^{* *}$ & 1 \\
\hline $\begin{array}{l}\text { Services/products offered } \\
\text { with a great variety }\end{array}$ & Sig. (2-tailed) & 0.000 & \\
\hline during COVID-19 & $\mathrm{N}$ & 250 & 250 \\
\hline
\end{tabular}

**. Correlation is significant at the 0.01 level (2-tailed).

Table 3. Testing the second hypothesis.

\begin{tabular}{|c|c|c|c|}
\hline \multicolumn{4}{|c|}{ Correlations } \\
\hline & & $\begin{array}{l}\text { Time saving while using } \\
\text { services/products offered } \\
\text { online during COVID-19 }\end{array}$ & $\begin{array}{c}\text { Price and quality of } \\
\text { services/products during } \\
\text { COVID-19 }\end{array}$ \\
\hline \multirow{3}{*}{$\begin{array}{l}\text { Time saving while } \\
\text { using services/products } \\
\text { offered online during } \\
\text { COVID-19 }\end{array}$} & Pearson Correlation & 1 & $0.349^{* *}$ \\
\hline & Sig. (2-tailed) & & 0.000 \\
\hline & $\mathrm{N}$ & 250 & 250 \\
\hline \multirow{3}{*}{$\begin{array}{l}\text { Price and quality of } \\
\text { services/products } \\
\text { during COVID-19 }\end{array}$} & Pearson Correlation & $0.349^{* *}$ & 1 \\
\hline & Sig. (2-tailed) & 0.000 & \\
\hline & $\mathrm{N}$ & 250 & 250 \\
\hline
\end{tabular}

${ }^{* *}$. Correlation is significant at the 0.01 level (2-tailed). 
Table 4. Testing the third hypothesis.

\begin{tabular}{|c|c|c|c|}
\hline \multicolumn{4}{|c|}{ Correlations } \\
\hline & & $\begin{array}{l}\text { Socialism during the online } \\
\text { shopping with family and } \\
\text { friends during COVID - } 19\end{array}$ & $\begin{array}{c}\text { The online shopping } \\
\text { behavior during } \\
\text { COVID-19 }\end{array}$ \\
\hline Socialism during the & Pearson Correlation & 1 & $0.233^{* *}$ \\
\hline $\begin{array}{l}\text { online shopping with } \\
\text { family and friends }\end{array}$ & Sig. (2-tailed) & & 0.000 \\
\hline during COVID-19 & $\mathrm{N}$ & 250 & 250 \\
\hline The online shopping & Pearson Correlation & $0.233^{* *}$ & 1 \\
\hline behavior during & Sig. (2-tailed) & 0.000 & \\
\hline COVID-19 & $\mathrm{N}$ & 250 & 250 \\
\hline
\end{tabular}

**. Correlation is significant at the 0.01 level (2-tailed).

\subsection{Testing the Third Hypothesis}

H3o: There is a significant positive correlation in socialism during the online shopping with family and friends during COVID-19 and the online shopping behavior.

H3o: There is no significant correlation socialism during the online shopping with family and friends during COVID-19 and the online shopping behavior.

The results from the correlation analysis test show that there is a strong positive correlation between the tested variables, which are statistically expressed with a correlation level of $r=0.233$ and a significance level of Sig $=0<0.05$ (Table 4). The analysis shows that with the increase of the variable $\mathrm{X}$ the variable Y decreases, which means that the more people socialize, while online shopping with family and friends during COVID-19, the more there is a noticeable change in behavior and a change in shopping done before. Consequently, this makes us accept the null hypothesis. These results show a great similarity with the previous findings of different researchers on the relationship between these two variables.

\section{Conclusions}

In this study, we examined the demographic profile of the consumers and their impact on online shopping and identify the factors affecting online buyers' behavior. Online shopping is becoming more popular day by day with the increase in the usage of internet because it is integral part of our life nowadays.

Due to technological innovation, the traditional mode of purchase has become inadequate for some individuals especially in this year. People now prefer simpler modes for acquiring brands and reaching stores, and it can be stated that the Internet has fundamentally changed the consumers' ideas on convenience, speed, price etc.

Companies need to know who their buyers are, and what drives them in order to maximize their marketing planning (Lescher, 1995) [51]. Additionally, even if a product seems suitable for a customer, he/she has to have a belief that buying 
this item online is safe and the stronger this belief is, the more likely their intentions to purchase online are (Gefen \& Straub, 2004) [52]. For some people this is easy, some need more convincing.

With the start of COVID-19, buying online industry is observing a peculiar increase internationally and with the world heading into a foreseeable worldwide recession, the development of the industry is bound to slow down. The rising market is now witnessing the lively enlargement of internet shopping.

The research examines the factors influencing consumers' internet shopping behavior during the coronavirus disease (COVID-19) pandemic in the Republic of Kosovo. The study presents and evaluates the impact of seven factors: convenience, pricing and quality, website design, saving time, security and socialization effects on consumers' internet shopping behavior during the coronavirus disease (COVID-19) pandemic.

The limitation of our research is in way of sampling because the pandemic time of COVID-19. The participants of our survey may have been asked in another way, not only through the use of opportunities offered by the Internet such as social networks, but also through the distribution of the questionnaire in physical form, but the period was unfavorable for this. It can be expected various answers to study questions in the other age categories and forms of survey.

\section{Conflicts of Interest}

The authors declare no conflicts of interest regarding the publication of this paper.

\section{References}

[1] Trong, V., Vu Khanh, N. and Gim, G. (2014) Evaluating Factors Influencing Consumer Satisfaction towards Online Shopping in Viet Nam. Journal of Emerging Trends in Computing and Information Sciences, 5, 67-71.

[2] Singh, A. and Sailo, M. (2013) Consumer Behavior in Online Shopping: A Study of Aizawl. International Journal of Business \& Management Research, 1, 45-49.

[3] Bourlakis, M., Papagiannidis, S. and Fox, H. (2008) E-Consumer Behaviour: Past, Present and Future Trajectories of an Evolving Retail Revolution. International Journal of E-Business Research, 4, 64-76. https://doi.org/10.4018/jebr.2008070104

[4] Aref, M. and Okasha, A. (2019) Evaluating the Online Shopping Behavior among Egyptian College-Educated Community. Review of Economics and Political Science, 5, 21-37. https://doi.org/10.1108/REPS-10-2018-0013

[5] Katawetawaraks, C. and Wang, C.L. (2011) Online Shopper Behavior: Influences of Online Shopping Decision. Asian Journal of Business Research, 1, 66-74. https://doi.org/10.14707/ajbr.110012

[6] Ahmad, S. (2002) Service Failures and Customer Defection: A Closer Look at Online Shopping Experiences. Managing Service Quality, 12, 19-29. https://doi.org/10.1108/09604520210415362

[7] Rahman, M., Islam, M., Esha, B., Sultana, N. and Chakravorty, S. (2018) Consumer Buying Behavior towards Online Shopping: An Empirical Study on Dhaka City, Bangladesh. Cogent Business \& Management, 5, Article: 1514940. https://doi.org/10.1080/23311975.2018.1514940 
[8] Hostler, R.E., Yoon, V.Y. and Guimaraes, T. (2012) Recommendation Agent Impact on Consumer Online Shopping: The Movie Magic Case Study. Expert Systems with Applications, 39, 2989-2999. https://doi.org/10.1016/j.eswa.2011.08.160

[9] Sung, T.K. (2006) E-Shopping Critical Success Factors: East vs. West. Technological Forecasting and Social Change, 79, 1161-1177. https://doi.org/10.1016/j.techfore.2004.09.002

[10] Berry, L., Seiders, K. and Grewal, D. (2002) Understanding Service Convenience. Journal of Marketing, 66, 1-17. https://doi.org/10.1509/jmkg.66.3.1.18505

[11] Copeland, M. (1923) "Relation of Consumers" Buying Habits to Marketing Methods. Harvard Business Review, 1, 282-289.

[12] Bucklin, L.P. (1965) Retail Strategy and the Classification of Consumer Goods. Journal of Marketing, 27, 50-55. https://doi.org/10.1177/002224296302700110

[13] Brown, L.G. (1989) The Strategic and Tactical Implications of Convenience in Consumer Product Marketing. Journal of Consumer Marketing, 6, 13-19. https://doi.org/10.1108/EUM0000000002550

[14] Hamza, V. and Saidalavi, K. (2014) A Study on Online Shopping Experience and Customer Satisfaction. Advances in Management, 7, 38-42.

[15] Prasad, C. and Aryasri, A. (2009) Determinants of Shopper Behaviour in E-Tailing: An Empirical Analysis. Paradigm, 13, 73-83. https://doi.org/10.1177/0971890720090110

[16] Parasuraman, A., Zeithaml, V. and Berry, L. (1985) A Conceptual Model of Service Quality and Its Implications for Future Research. Journal of Marketing, 49, 41-50. https://doi.org/10.1177/002224298504900403

[17] Joseph Cronin, J., Brady, M. and Hult, G. (2000) Assessing the Effects of Quality, Value, and Customer Satisfaction on Consumer Behavioral Intentions in Service Environments. Journal of Retailing, 76, 193-218. https://doi.org/10.1016/S0022-4359(00)00028-2

[18] Zeithaml, V.A. (1988) Consumer Perceptions of Price, Quality, and Value: A Means-End Model and Synthesis of Evidence. Journal of Marketing, 52, 2-22. https://doi.org/10.1177/002224298805200302

[19] Jiang, P. and Rosenbloom, B. (2005) Customer Intention to Return Online: Price Perception, Attribute-Level Performance, and Satisfaction Unfolding over Time. European Journal of Marketing, 39, 150-174. https://doi.org/10.1108/03090560510572061

[20] Kim, H.-W., Xu, Y. and Gupta, S. (2012) Which Is More Important in Internet Shopping, Perceived Price or Trust? Electronic Shopping Research and Applications, 11, 241-252. https://doi.org/10.1016/j.elerap.2011.06.003

[21] Mittal, B. (1989) Measuring Purchase-Decision Involvement. Psychology \& Marketing, 6, 147-162. https://doi.org/10.1002/mar.4220060206

[22] Keaveney, S. (1995) Customer Switching Behavior in Service Industries: An Exploratory Study. Journal of Marketing, 59, 71-82. https://doi.org/10.1177/002224299505900206

[23] Jiradilok, T., Malisuwan, S., Madan, N. and Sivarak, J. (2014) The Impact of Customer Satisfaction on Online Purchasing: A Case Study Analysis in Thailand. Journal of Economics, Business and Management, 2, 5-11. https://doi.org/10.7763/JOEBM.2014.V2.89

[24] Biswas, A. and Blair, E. (1991) Contextual Effects of Reference Prices in Retail Advertisements. Journal of Marketing, 55, 1-12. https://doi.org/10.1177/002224299105500301 
[25] Liu, C. and Arnett, K. (2000) Exploring the Factors Associated with Web Site Success in the Context of Electronic Shopping. Information \& Management, 38, 23-33. https://doi.org/10.1016/S0378-7206(00)00049-5

[26] Lim, H. and Dubinsky, A. (2004) Consumers' Perceptions of e-Shopping Characteristics: An Expectancy-Value Approach. Journal of Services Marketing, 18, 500-513. https://doi.org/10.1108/08876040410561839

[27] Lin, C.-C., Wu, H.-Y. and Chang, Y.-F. (2011) The Critical Factors Impact on Online Customer Satisfaction. Procedia Computer Science, 3, 276-281.

https://doi.org/10.1016/j.procs.2010.12.047

[28] Chen, Z. and Dubinsky, A.J. (2003) A Conceptual Model of Perceived Customer Value in e-Commerce: A Preliminary Investigation. Psychology \& Marketing, 20, 323-347. https://doi.org/10.1002/mar.10076

[29] Keeney, R.L. (1999) The Value of Internet Shopping to the Customer. Management Science, 45, 533-542. https://doi.org/10.1287/mnsc.45.4.533

[30] Mentzer, T. and Williams, L. (2008) The Role of Logistics Leverage in Marketing Strategy. Journal of Marketing Channels, 8, 29-47. https://doi.org/10.1300/J049v08n03_03

[31] Kim, S. and Stoel, L. (2004) Apparel Retailers: Web Site Quality Dimensions and Satisfaction. Journal of Retailing and Consumer Services, 11, 109-117. https://doi.org/10.1016/S0969-6989(03)00010-9

[32] Guo, X., Ling, K.C. and Liu, M. (2012) Evaluating Factors Influencing Consumer Satisfaction towards Online Shopping in China. Canadian Center of Science and Education, 8, 40-50. https://doi.org/10.5539/ass.v8n13p40

[33] Christodoulides, G. and Michaelidou, N. (2010) Shopping Motives as Antecedents of e-Satisfaction and e-Loyalty. Journal of Marketing Management, 27, 181-197. https://doi.org/10.1080/0267257X.2010.489815

[34] Laudon, K. and Traver, C. (2009) E-Shopping Business. Technology. Society (5 ed.). Prentice Hall, Upper Saddle River.

[35] Bigné-Alcañiz, E., Ruiz-Mafé, C., Aldás-Manzano, J. and Sanz-Blas, S. (2008) Influence of Online Shopping Information Dependency and Innovativeness on Internet Shopping Adoption. Online Information Review, 32, 648-667. https://doi.org/10.1108/14684520810914025

[36] Koo, D.-M., Kim, J.-J. and Lee, S.-H. (2008) Personal Values as Underlying Motives of Shopping Online. Asia Pacific Journal of Marketing and Logistics, 20, 156-173. https://doi.org/10.1108/13555850810864533

[37] Broekhuizen, T. and Huizingh, E. (2009) Online Purchase Determinants: Is Their Effect Moderated by Direct Experience? Management Research News, 32, 440-457. https://doi.org/10.1108/01409170910952949

[38] Wang, C.L., Zhang, Y., Ye, L. and Nguyen, D.-D. (2005) Subscription to Fee-Based Online Services: What Makes Consumer Pay For Online Content? Journal of Electronic Shopping Research, 6, 304-311.

[39] Bhatnagar, A., Sanjog, M. and Rao, H.R. (2000) On Risk, Convenience, and Internet Shopping Behavior. Communications of the ACM, 43, 98-105.

https://doi.org/10.1145/353360.353371

[40] Rohm, A.J. and Swaminathan, V. (2004) A Typology of Online Shoppers Based on Shopping Motivations. Journal of Business Research, 57, 748-757.

https://doi.org/10.1016/S0148-2963(02)00351-X

[41] Corbett, J. (2001) Is Online Grocery Shopping Increasing in Strength? Journal of 
Food Distribution Research, 3, 37-40.

[42] Morganosky, M.A. and Cude, B.J. (2000) Consumer Response to Online Grocery Shopping. International Journal of Retail \& Distribution Management, 28, 17-26. https://doi.org/10.1108/09590550010306737

[43] Goldsmith, R. and Bridges, E. (2000) E-Tailing vs. Retailing: Using Attitudes to Predict Online Buyer Behavior. Quarterly Journal of Electronic Shopping, 1, 245-253.

[44] Kim, S. and Lim, Y. (2001) Consumers' Perceived Importance of and Satisfaction with Internet Shopping. Electronic Markets, 11, 148-154. https://doi.org/10.1080/101967801681007988

[45] Childers, T.L., Carr, C.L., Peck, J. and Carson, S. (2001) Hedonic and Utilitarian Motivations for Online Retail Shopping Behavior. Journal of Retailing, 77, 511-535. https://doi.org/10.1016/S0022-4359(01)00056-2

[46] Pilík, M. and Juřičková, E. (2016) Trust and Security as Significant Factors Influencing On-Line Buying Behaviour in the Czech Republic. Economics Management Innovation, 8, No. 2.

[47] Eid, M. (2011) Determinants of E-Shopping Customer Satisfaction, Trust, and Loyalty in Saudi Arabia. Journal of Electronic Shopping Research, 12, 78-93.

[48] Lee, J.-Y. and Jin, C.-H. (2019) The Role of Ethical Marketing Issues in Consumer-Brand Relationship. Sustainability, 11, 6536. https://doi.org/10.3390/su11236536

[49] Chen, R. and He, F. (2010) Examination of Brand Knowledge, Perceived Risk and Consumers' Intention to Adopt an Online Retailer. Total Quality Management \& Business Excellence, 14, 677-693. https://doi.org/10.1080/1478336032000053825

[50] Comegys, C., Hannula, M. and Väisänen, J. (2009) Effects of Consumer Trust and Risk on Online Purchase Decision-Making: A Comparison of Finnish and United States Students. International Journal of Management, 26, 295-308.

[51] Lescher, J.F. (1995) Online Market Research: Cost-Effective Searching of the Internet and Online Databases (Vol. 1). Addison-Wesley Professional, Canada.

[52] Gefen, D. and Straub, D.W. (2004) Consumer Trust in B2C e-Shopping and the Importance of Social Presence: Experiments in e-Products and e-Services. Omega, 32, 407-424. https://doi.org/10.1016/j.omega.2004.01.006 